\title{
SEXUALLY TRANSMITTED INFECTIONS IN THE RESIDUAL FORCES PARTICIPATING IN MILITARY MISSIONS - DIAGNOSTIC AND PROPHYLACTIC PROCEEDINGS
}

\author{
Maria GOŁĘBIOWSKA-WAWRZYNIAK', Katarzyna MARKIEWICZ', Tomasz \\ MACIEJEWSKI ${ }^{1}$, Artur JAKIMIUK ${ }^{2}$, Olaf TRUSZCZYŃSKI ${ }^{3}$, Tomasz KOZICKI ${ }^{3}$, Andrzej \\ MODRZEWSKI ${ }^{3}$, Agata KOZAR ${ }^{1}$, Zbigniew WAWRZYNIAK ${ }^{4}$, Krzysztof RYTWIŃSKI $^{1}$ \\ ${ }^{1}$ Institute of Mother and Child, Warsaw, Poland \\ ${ }^{2}$ Central Clinical Hospital of the Ministry of Interior, Warsaw, Poland \\ ${ }^{3}$ Military Institute of Aviation Medicine, Warsaw, Poland \\ ${ }^{4}$ Medical University of Warsaw, Warsaw, Poland
}

Source of support: Own sources

Author's address: M. Gołębiowska-Wawrzyniak, Institute of Mother and Child, e-mail: zaklad.immunologii@imid.med.pl

Introduction: The number of women on military missions has been increasing recently. While on military missions, they live in an isolated group dominated by men. Such groups consist of young, sexually active individuals, thus increasing the risk of sexually transmitted infections.

Methods: Medical examinations were performed on various residual forces (military, police, security guards) totaling 579 individuals, up to 35 years of age (172 women and 407 men). Subjects qualified for the study were divided into 2 groups. Group I consisted of persons who remained in the country. Group II included persons stationed on military missions abroad. A total of 306 soldiers from this group participated in Study 1. Study 2 (clinical and laboratory) was carried out 6-12 months later on 52 patients from Group II and 119 patients from Group I (84 women and 87 men). Additionally, transcription of HPV genes E6 and E7 (with high oncogenic risk) was carried out in the group made up of 200 women. Laboratory examinations included: peripheral blood morphology, lymphocyte subpopulations by flow cytometry method (CD45, CD3, CD19, CD4, CD8 markers and NK cells CD16+CD56 markers), IL-2, IL-4, TNF- $\alpha$, IFN- $\gamma$, IL-18 concentration by flow cytometry method. $\lg$, $\lg \mathrm{A}$, IgM concentration by turbidimetric method and

Tables: 13 - Figures: 0 - References: 21 - Full-text PDF: http://www.pjamp.com • Copyright (C) 2013 Polish Aviation Medicine Society, ul. Krasińskiego 54/56, 01-755 Warsaw, license WIML • Indexation: Index Copernicus, Polish Ministry of Science and Higher Education 
IgE concentration by ELISA method. Determination of anti-HSV-2, HIV and Chlamydia trachomatis antibodies by ELISA method. For the assessment of HPV infections, DNA extracted from cervical squamous epithelial cells was tested by PCR, HPV genotype was examined via the expression of E6 and E7 oncogenes of HPV 16,18,33,35,45 strains by real-time NASBA.

Results: In a group of 579 individuals, HPV infection was confirmed in 41 men (10\%) and 24 women (14.8\%). HSV-2 test was positive in 17 persons: 6 men (1.5\%) and 11 women (6.4\%). Chlamydia trachomatis infection was confirmed in 10 patients: 6 men (1.5\%) and 4 women (2.3\%). HIV test was negative. Following a period of 6 months, further tests were conducted on 171 individuals from a group of 579 subjects. HPV infection was detected in 22 individuals (12.9\%) - 13 men (14.9\%) and 9 women (10.8\%). HSV-2 was detected in 11 cases -2 men (2.3\%) and 9 women (10.7\%). Chlamydia trachomatis was detected in 4 persons - 2 men (2.3\%) and 2 women (2.4\%). Immunological parameters in the examined groups were without significant variations.

Conclusions: 1) The frequency of HPV, HIV, HSV-2 and Chlamydia trachomatis infections was lower in the residual forces than in the general Polish population or the rates published in medical publications throughout the world.

2) The investigation did not find an increase in the frequency of HSV-2, Chlamydia trachomatis, HIV and HPV infections in the groups of individuals on military missions abroad, as compared to those who remained in the country.

Keywords: infections, HSV-2, Chlamydia trachomatis, HIV, HPV, immunodeficiency

\section{INTRODUCTION}

In the situation of an increased incidence of sexually transmitted diseases and the related consequences, it is justified to conduct extensive research on the development of new methods for accurate diagnosis, early identification of infection, causal treatment and especially the implementation of prevention.

A very important issue in the context of sexually transmitted diseases is an increasing presence of women in the residual forces. Their presence in the uniformed services creates the need for more research concerning the issues that may arise due to their participation. Since 1988, women in Poland have been allowed to join the military. According to data published by the Public Opinion Research Center, in 1990 there were 32 women serving in the Polish army, by 1995 that number rose to over 100, 5 years later - almost 300 , in 2005 just under 600 [11] and in 2006, more than 650 women served in the army [12]. In 2007, the number of women serving in the military had increased to 800 . The number of female candidates for professional military positions surpassed 1000. Individuals relocating to military missions abroad must adjust to the new environment and lifestyle. During military missions, the cohabitation in an isolated group of young men and women significantly increases the risk of infection with sexually transmitted diseases. According to data from the world literature, the most common sexually transmitted infections in a population of quartered, sexually active young men and women, include HPV, HIV, HSV-2 and Chlamydia trachomatis [20].

Particularly dangerous and oncogenic HPV is spread through sexual contact. Both men and women act as reservoirs, therefore screening of both groups is necessary for prevention of infection [18]. According to data from epidemiological studies, $30-60 \%$ of sexually active Poles are infected with genital HPV types [7]. High incidence of latent HPV infection is a clinically significant issue. Pathogen identification requires cytological and molecular studies to identify the type of virus present (low- or high-risk). Those infected, must then be carefully and frequently managed by a gynecologist to help prevent the development of cervical cancer. Routine Pap smears can only confirm or exclude morphological changes in the cervical epithelial cells, without providing any clues regarding viral DNA's integration into the host's DNA. Therefore, Pap smear can not recognize HPV infection, nor determine its genotype. An effective way to detect viral DNA is through molecular tests. Most common tests mark the HPV DNA in a cervical swab using genetic techniques, primarily PCR (polymerase chain reaction). However, these 
studies do not detect persistent infections in which HPV DNA was integrated into the genome of squamous cells. In such cases, test results for the presence of viral DNA are negative. Test does not provide information regarding the development of potential epithelial neoplasia [2]. Chronic infection lasting a few months may be detected by another test that detects high-risk HPV (HR-HPV) mRNA oncogenes E6 and E7 (PreTect HPV-Proofer assay) [9]. This method uses mRNA amplification reaction for the 5 types of highly-oncogenic HPV strains - 16, 18, 31, 33 and 45 . A positive result confirms chronic infection in which the viruses lost their mechanism of control and are capable of producing oncogenic protein contributing to tumorigenesis [6]. In 2008-2011, the implementation of the Development Program concerning the screening for particularly important sexually transmitted infections and the development of preventive and therapeutic algorithm in the residual forces, including those on military missions, allowed for the identification of HPV mRNA in a group of 300 women aged 20-35 years. The research was carried out once. In 25 women, E6/ E7 oncogene mRNA transcripts were detected. In $32 \%$ of these women, Pap smear results were normal in spite of persistent HR-HPV infection - group I by Papanicolaou, NILM (No Intraepithelial Lesion or Malignancy) by Bethesda system 2001.

The results and conclusions obtained following the implementation of the Development Program validate the rationale for further studies of infection with oncogenic types of HPV.

Valid cytology and negative results of HR-HPV DNA test do not confirm the absence of chronic HPV infection, which often leads to cervical cancer. In Poland, 3,600 women are diagnosed with this type of cancer annually, while approximately 2,000 die from it every year - this is one of the highest ratios in Europe (9.4/100,000; data from 2004) [5]. In view of the significance of the problem for determining the prevalence of chronic infection, it is advisable to extend the scope of screening in young women. Diagnostic confirmation of chronic HPV infection enables gynecologists to identify women at higher risk of developing cervical cancer early and manage them with proper specialist medical care. This is especially true considering the fact that the peak for detection of HPV infection occurs in the age group 18-25 years, with peak cervical cancer incidence occurring around the age of 50. Prevalence screening for persistent infection may be part of a cervical cancer prevention program.
Human immunodeficiency virus (HIV) is the etiological factor for the acquired immune deficiency syndrome (AIDS). HIV can lead to infections with opportunistic pathogens (Pneumocystis spp., Toxoplasma gondii, Candida albicans, cytomegalovirus), can cause cancer, including cervical cancer with a high-grade dysplasia, it can also cause degeneration of the nervous system. Transmission of the virus occurs through sexual contact, heterosexual (80\%) and homosexual, through contaminated blood or blood products, from mother to child during the last trimester of pregnancy or during childbirth and breastfeeding [16].

In 2011, 1,290 HIV infections were diagnosed in Poland. This represents more than a double increase in infections compared to the time period 2000-2010. This increase applies only to men [13].

HSV-2 causes mainly genital herpes, but it could also lead to cancer. Despite therapy, infection persists until the end of life. It is estimated that $60 \%$ of infections are undiagnosed, which is the result of insufficient medical testing [3]. Infection occurs through direct contact between an individual shedding the virus with damaged skin or undamaged mucosa of the recipient. Men excrete virus more frequently due to anatomical differences. During sexual contact, women are 4 times more likely to become infected than men. The risk of infection other than through sexual contact is minimal.

According to the WHO (2003 data), there were 536 million individuals infected with HSV-2 worldwide $(315 \mathrm{mln}$ women and $221 \mathrm{mln}$ men between the ages 14 and 49). Frequency of infection is highest in persons around the age of 40 . Only $10-25 \%$ of those infected are aware of their diagnosis [7].

In the time period 1990-2003, HSV-2 infection rate was less than 2 per 100,000 individuals. In 2007, 193 cases were recorded in Poland [14]. Medical consequences of HSV-2 genital infection include the possibility of fetal or newborn infection during pregnancy and synergism with HIV infection. HSV infection stimulates the expression of CCR5 on CD4+ lymphocytes, which increases the risk of HIV infection. HSV infection causes breaks in the continuity of the skin and mucosa, increasing the risk of HIV infection.

Chlamydia trachomatis is a mostly sexually transmitted microbe. Risk factors for $\mathrm{C}$. trachomatis infection include: young age, multiple sexual partners, hormonal contraception. C.trachomatis infections are mostly observed in the population of young women, however $70 \%$ of infections are asymptomatic. Inflammation of minor pelvic organs is a commonly observed complication, potentially leading to tubal infertility [4]. 
C.trachomatis facilitates HPV infection by sustaining inflammation and modifying local epithelial immunity. Infection with the pathogen often coincides with the presence of high risk HPV [17]. According to some authors, C.trachomatis infection can cause epithelial dysplasia or cervical cancer [1]. In men, the most common forms of C.trachomatis include NGU (Non-gonococcal urethritis), epididymitis, especially in young men under 35 y.o., which could cause obstruction of the seminiferous tubules and male infertility. Chlamydial infection may lead to reactive arthritis, which occurs more commonly in men. Infectious agent may trigger immunological process by both cellular and humoral immune response, although no evidence of microorganism within the joint is detected. Inflammation of the synovial tendon connective tissue capsule is observed [10].

According to the 2004 data, infection rate of Chlamydia trachomatis in Poland ranged between $20 \%$ and $40 \%$ [21]. Data concerning Chlamydia trachomatis infection rate after 2010 is lacking.

The objective was to conduct screening and develop a thorough prevention and treatment guideline for specific sexually transmitted diseases among residual forces stationed at home and abroad.

\section{METHODS}

The immune system prevents inflammation, which arises as a result of viral or bacterial infections. Its condition was assessed by testing blood cell subpopulations using flow cytometry - basic immune panel, cytokine concentrations: IL-2, 4, 18, TNF- $\alpha$, IFN- $\gamma$ and immunoglobulin $E$ (total lgE) as a potential factor in allergic diseases. In order to diagnose Chlamydia trachomatis infection, HSV-2 and HIV, serum levels of IgM and IgG antibodies were measured. HPV infection was diagnosed using labeled viral DNA in the squamous epithelial cells of urogenital organs. The survey covered residual forces (military, police, municipal police, border service), examining a total of 579 individuals, up to 35 years of age (172 women and 407 men). Subjects qualified for the study were divided in 2 groups. Group I included individuals who remained in the country. Group II consisted of those who participated in military missions abroad. Clinical and laboratory tests were performed at the beginning ( Study 1) and after a period of 6-12 months (Study 2). One hundred seventy-one subjects took part in Study 2 (84 women, 87 men). Additionally, E6 and E7 gene transcript of high-risk HPV was marked in a group of 200 women. It was not possible to reach women stationed on military missions, hence Group II consisted only of 306 male soldiers. Re-examinations were performed on 53 individuals from this group. The remaining male subjects from Group 2 could not take part in re-examinations due to mission prolongation.

Laboratory tests were conducted with the approval of the Institute of Mother and Child Bioethical Committee, as well as with the informed consent of all test groups.

During the study, laboratory tests consisted of: a) complete blood count,

b) subpopulations of blood cells using monoclonal antibodies by flow cytometry - basic immune panel: CD14/CD45, CD3, CD19, CD4, CD8, CD16+CD56 (NK),

c) concentration of cytokines: IL-2, IL-4, TNF- $\alpha$, IFN $-\gamma$, IL-18 by flow cytometry method,

d) concentration of $\lg G, \lg A$, $\lg M$ by turbidimetric method and concentration of total lgE using ELISA (Enzyme-Linked Immunosorbent Assay),

e) detection of anti-HSV-2, anti-HIV and anti-Chlamydia trachomatis antibodies using ELISA,

f) detection of HPV antigen using PCR (polymerase chain reaction),

g) defining HPV genotype by expression analysis $\operatorname{HPV}(16,18,33,35,45)$ E6 and E7 oncogene using PCR, NASBA type.

Blood cell immunophenotype was determined by flow cytometry. Lymphocyte subpopulations were marked using venous blood collected on EDTA and fluorochrome-labeled antibodies to facilitate the identification of T lymphocytes and their subpopulations, B lymphocytes and NK cells. The measurement was performed in 24 hours and probes were collected at a temperature of $4^{\circ} \mathrm{C}$. Serum concentration of immunereactive cytokines: IL-2, IL-4, TNF- $\alpha$, IFN- $\gamma$ was carried out using FlowCytomix Human Th1/Th2 11 plex Kit, Bender MedSystems company. Cytokine IL-18 concentration was determined using a similar kit.

ELISA was used in the analysis of a developing HSV or Chlamydia trachomatis infection utilizing anti-HSV and anti-Chlamydia antibodies. The diagnosis of HIV infection was based on ELFA technique in which fluorescence of the sample is measured spectrophotometrically.

HPV presence was detected by labeling its viral DNA in the squamous epithelial cells collected from the endocervical canal and the sulcus behind the corona of the glans. This method used specific oligonucleotide primers and DNA polymerase to multiply specific viral DNA sequences from the collected tissue. DNA identification occurred by means of hybridization techniques. For the pur- 
M. Gołębiowska-Wawrzyniak and al. - Sexually transmitted infections...

poses of chronic HPV infection confirmation, E6 and E7 viral transcripts were detected using molecular biology method (NASBA, real-time). The advantage of detecting mRNA transcripts over HPV DNA lies in the diagnosis of chronic infections where viruses may lose their ability to control and begin to synthesize oncogenic proteins affecting carcinogenesis.

The serum concentration of a particular immunoglobulin class was measured using turbidimetric method (Turbitimer TT3 device, BEHRING DIAGNOSTICS, INC.), which measures the intensity of light passing through a turbid medium formed after an immunochemical reaction. The results were recorded in international unit $/ \mathrm{ml}(\mathrm{IU} / \mathrm{ml})$. IgE concentration was measured by fluoroenzymatic method (FEIA, a type of ELISA technique) using ImmunoCAP Phadia-Pharmacia system.

\section{RESULTS}

\section{HSV 2 infection}

A total of 579 subjects took part in the study (172 women and 407 men). The tests were done twice - at the beginning (Study 1) and after a period of 6 months (Study 2). Study 2 involved 171 individuals (84 women, 87 men). HSV-2 infection was diagnosed by detecting specific viral antibodies measured in Virotech Units (VE). Concentration exceeding 11 VE was considered a positive result. No person with anti-HSV-2 IgM antibodies was detected in test group.

Among the tested 579 people, 306 were participants of military missions abroad (Group II) and 273 were stationed in the country (Group I). During Study 1, HSV-2 infection was confirmed in 4 cases (1.3\%) in Group II and in 13 cases (4.8\%) in Group I. During Study 2 consisting of 171 individuals out of the original 579, HSV-2 infection was confirmed in

Tab. 1. Change in the dynamics of HSV2 infection in Groups I and II (GR I, GR II) taking gender into account. Study 1 (exam.1) and Study 2 (exam. 2).

\begin{tabular}{|c|c|c|c|c|c|c|c|}
\hline \multicolumn{8}{|c|}{ The crossbreed table: IgG HSV2 exam. 1 - IgG HSV2 exam.2-Group-S } \\
\hline \multirow[t]{2}{*}{ Sex } & \multicolumn{4}{|c|}{ Group } & \multicolumn{2}{|c|}{ IgG HSV2 exam.2 } & \multirow{2}{*}{$\begin{array}{r}\text { Exam. } 1 \\
\text { Total }\end{array}$} \\
\hline & & & & & Neg & Pos & \\
\hline \multirow[t]{9}{*}{$\mathbf{F}$} & GR I & IgG HSV2 exam. 1 & Neg & Amount & 74 & 3 & 77 \\
\hline & & & & $\%$ of IgG HSV2 exam. 1 & $96.1 \%$ & $3.9 \%$ & $100 \%$ \\
\hline & & & & $\%$ of IgG HSV2 exam. 2 & $98.7 \%$ & $33.3 \%$ & $91.7 \%$ \\
\hline & & & Pos & Amount & 1 & 6 & 7 \\
\hline & & & & $\%$ of IgG HSV2 exam. 1 & $14.3 \%$ & $85.7 \%$ & $100 \%$ \\
\hline & & & & $\%$ of IgG HSV2 exam. 2 & $1.3 \%$ & $66.7 \%$ & $8.3 \%$ \\
\hline & & Total & & Amount & 75 & 9 & 84 \\
\hline & & & & $\%$ of IgG HSV2 exam. 1 & $89.3 \%$ & $10.7 \%$ & $100 \%$ \\
\hline & & & & $\%$ of IgG HSV2 exam. 2 & $100 \%$ & $100 \%$ & $100 \%$ \\
\hline \multirow[t]{18}{*}{ M } & GR II & IgG HSV2 exam.1 & Neg & Amount & 51 & 0 & 51 \\
\hline & & & & $\%$ of IgG HSV2 exam. 1 & $100 \%$ & $0 \%$ & $100 \%$ \\
\hline & & & & $\%$ of IgG HSV2 exam. 2 & $100 \%$ & $0 \%$ & $98.1 \%$ \\
\hline & & & Pos & Amount & 0 & 1 & 1 \\
\hline & & & & $\%$ of IgG HSV2 exam. 1 & $0 \%$ & $100 \%$ & $100 \%$ \\
\hline & & & & $\%$ of IgG HSV2 exam. 2 & $0 \%$ & $100 \%$ & $1.9 \%$ \\
\hline & & Total & & Amount & 51 & 1 & 52 \\
\hline & & & & $\%$ of IgG HSV2 exam. 1 & $98.1 \%$ & $1.9 \%$ & $100 \%$ \\
\hline & & & & $\%$ of IgG HSV2 exam. 2 & $100 \%$ & $100 \%$ & $100 \%$ \\
\hline & GR I & IgG HSV2 exam. 1 & Neg & Amount & 34 & 0 & 34 \\
\hline & & & & $\%$ of IgG HSV2 exam. 1 & $100 \%$ & $0 \%$ & $100 \%$ \\
\hline & & & & $\%$ of IgG HSV2 exam. 2 & $100 \%$ & $0 \%$ & $97.1 \%$ \\
\hline & & & Pos & Amount & 0 & 1 & 1 \\
\hline & & & & $\%$ of IgG HSV2 exam. 1 & $0 \%$ & $100 \%$ & $100 \%$ \\
\hline & & & & $\%$ of IgG HSV2 exam. 2 & $0 \%$ & $100 \%$ & $2.9 \%$ \\
\hline & & Total & & Amount & 34 & 1 & 35 \\
\hline & & & & $\%$ of IgG HSV2 exam. 1 & $97.1 \%$ & $2.9 \%$ & $100 \%$ \\
\hline & & & & $\%$ of IgG HSV2 exam. 2 & $100 \%$ & $100 \%$ & $100 \%$ \\
\hline
\end{tabular}

F-female, M-male 


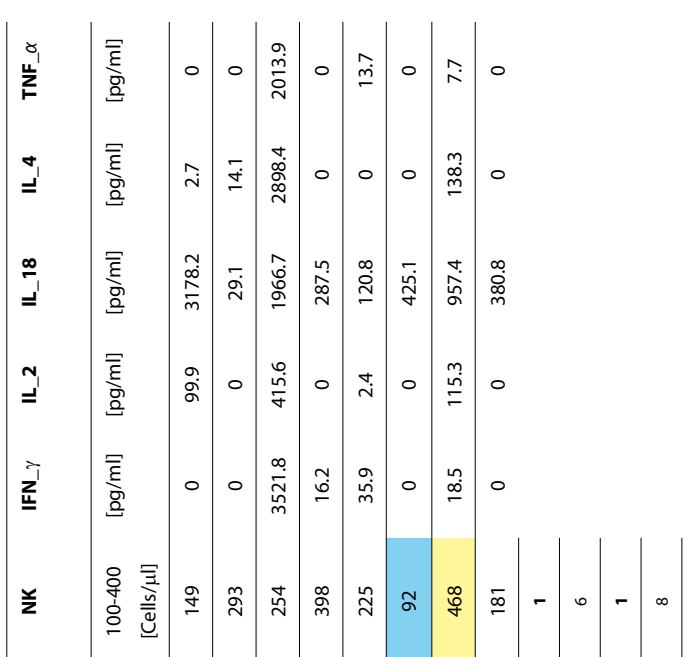

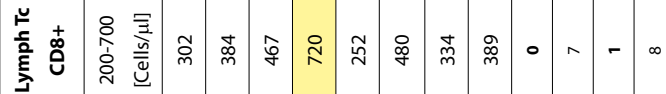

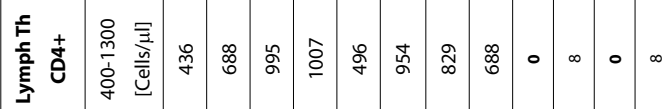

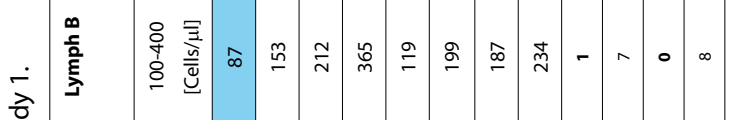

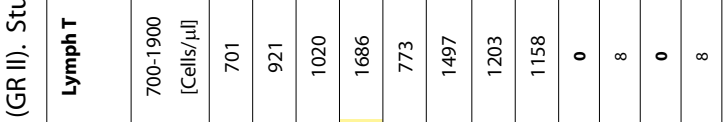

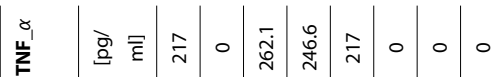

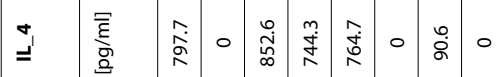

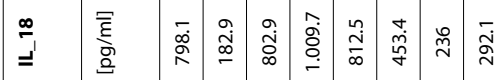

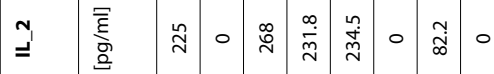

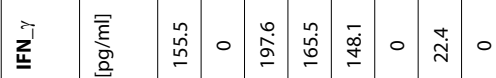

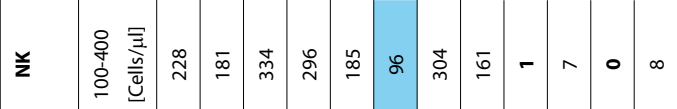

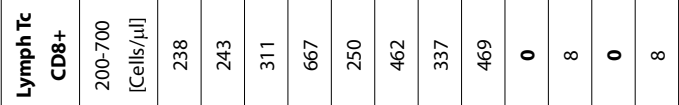

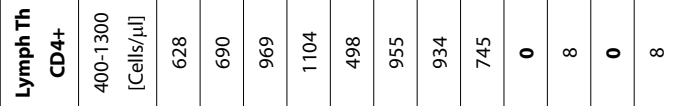
颃

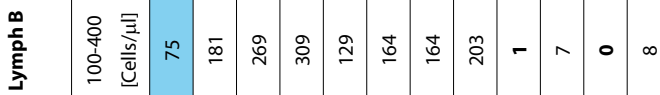

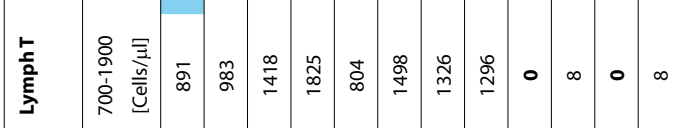

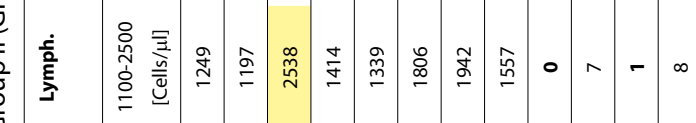

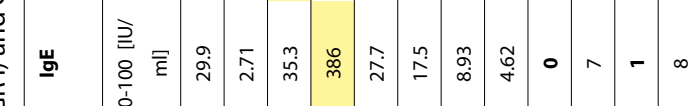

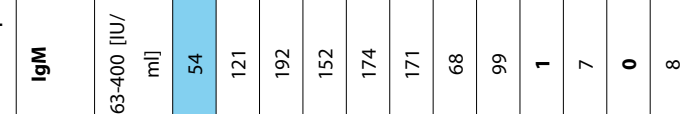

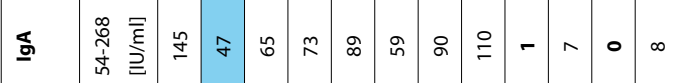

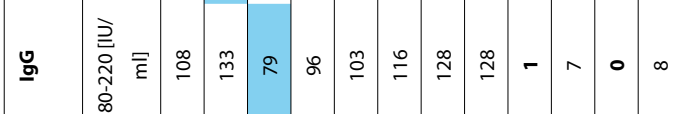

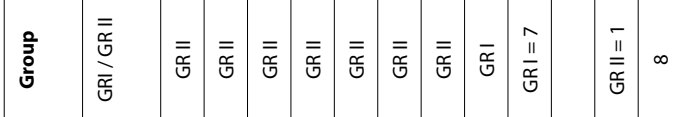

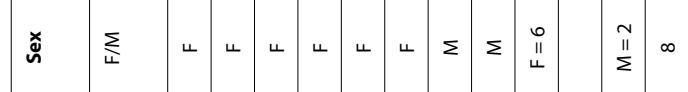

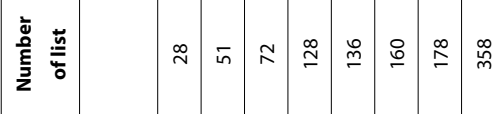


1 out of 52 individuals from Group II (1.9\%) and in 10 out of 119 individuals from Group I (8.4\%).

Table 1 presents the dynamics of an HSV-2 infection in Groups I and II, including both sexes during Study 1 and 2. During Study 1, HSV2 infection was confirmed in 7 out of 84 women in Group I. During Study 2 of the same group, the following results were found:

- 6 women continued to have a positive result; in 1 woman the infection was not confirmed,

- In 77 out of 84 women, HSV-2 infection test result was negative during Study 1; while in Study 2 negative result was confirmed in 74 out of 77 women, in 3 cases the result has changed from negative to positive.

Among 35 men from Group I, HSV-2 infection was confirmed in 1 case during Study 1 and 2 . HSV2 infection test result was negative in 34 cases during both studies.

In Group 2, a total of 52 male soldiers participated in both studies. Only 1 case (the same one in each study) of HSV-2 infection was confirmed during Study 1 and 2. Negative test results were confirmed in 51 men in both studies.

Tables 1 and 2 present test results of immunological profile parameters of the same patients who presented with IgG antibodies against HSV-2 ( 8 out of 17 positive results in test $1 ; 8$ out of 11 positive results in test $2 ; 6$ women and 2 men) during Study 1 and 2. One person infected with HSV-2 belonged to Group II (mission participant).

The following was observed during Study 1 (table 2) in 3 women from Group I (individuals who remained in the country):

- decreased IgA concentration - first woman,

- decreased IgM concentration and the number of B lymphocytes (CD19) - second woman,

- decreased number of NK cells was observed in a third woman.

During the second examination (Table 3), 1 immunocompromised person was confirmed with a decreasing concentration of lgG, while in case of the same 2 women from Study 1 decreasing concentration of $\lg A$ and $\operatorname{lgM}$ was observed. Moreover, in Study 2 there was a decrease in the number of $B$ lymphocytes and NK cells in the same women.

Analysis of cytokine concentrations had shown an increase in the median concentration of IFN- $\gamma$, IL-2, IL-18, IL-4 and TNF- $\alpha$ during Study 2 compared to the median concentrations of these cytokines during Study 1, a statistically not significant difference.

\section{Chlamydia trachomatis infection}

The study involved a total of 579 subjects (172 women and $407 \mathrm{men}), 170$ individuals participated in Study 2 (83 women, 87 men). Chlamydia trachomatis infection was determined by the presence of specific IgM and IgG antibodies measured in NTU (Novatec Unit). Positive result was determined with concentrations above 11 NTU. No Chlamydia trachomatis IgM antibody was confirmed in the group examined. Out of a total of 579 individuals, 306 left for missions abroad (Group II) and 273 remained in the country (Group I). In Study 1, Chlamydia trachomatis infection was confirmed in 5 (50\%) patients from Group II and in 5 (50\%) patients from Group I. In Study 2, a re-examination consisting of 170 out of the original 579 patients, Chlamydia trachomatis infection was confirmed in $1(1.9 \%)$ out of 52 patients from Group II and in 3 (2.3\%) out of 118 patients from Group I.

Table 4 shows the dynamics of Chlamydia trachomatis infection in Groups I and II, by gender during Study 1 and 2.

Among 83 women from Group I, Chlamydia trachomatis infection in Study 1 was confirmed in 2

(2.4\%) women. Study 2 of the same group resulted in the following:

- one woman remained positive; while in another case the infection was not confirmed,

- in 81 (97.6\%) out of 83 women from Study 1, test result for Chlamydia trachomatis infection was negative; while in Study 2, a negative result was confirmed in 80 women from the group with initial negative results, in 1 case the result has changed to a positive.

In Study 1, among the 35 men in Group I, Chlamydia trachomatis infection was confirmed in 1 man (the same) in Studies 1 and 2. The remaining 34 men were negative for Chlamydia trachomatis infection in studies 1 and 2 .

In the second group of 52 soldiers, confirmation of Chlamydia trachomatis infection was related to the same man in Study 1 and 2. Negative results were confirmed in 51 men in both studies.

Tables 5 and 6 present test results of immunological parameter profiles of the same patients with positive IgG antibodies against Chlamydia trachomatis in Studies 1 and 2 ( 3 out of 10 positive cases in Study 1; 3 out of 4 positive cases in Study 2 - one woman and two men). One person infected with Chlamydia trachomatis belonged to Group II, while the other belonged to Group I.

In Study 1 (Table 13), decreased concentration of IgA was observed in one woman from group I (those who remained in the country). Other im- 
Original Article

Tab. 4. Change in the dynamics of Chlamydia trachomatis infection in Groups I and II (GR I, GR II), taking gender into account. Study 1 (exam.1) and Study 2 (exam. 2).

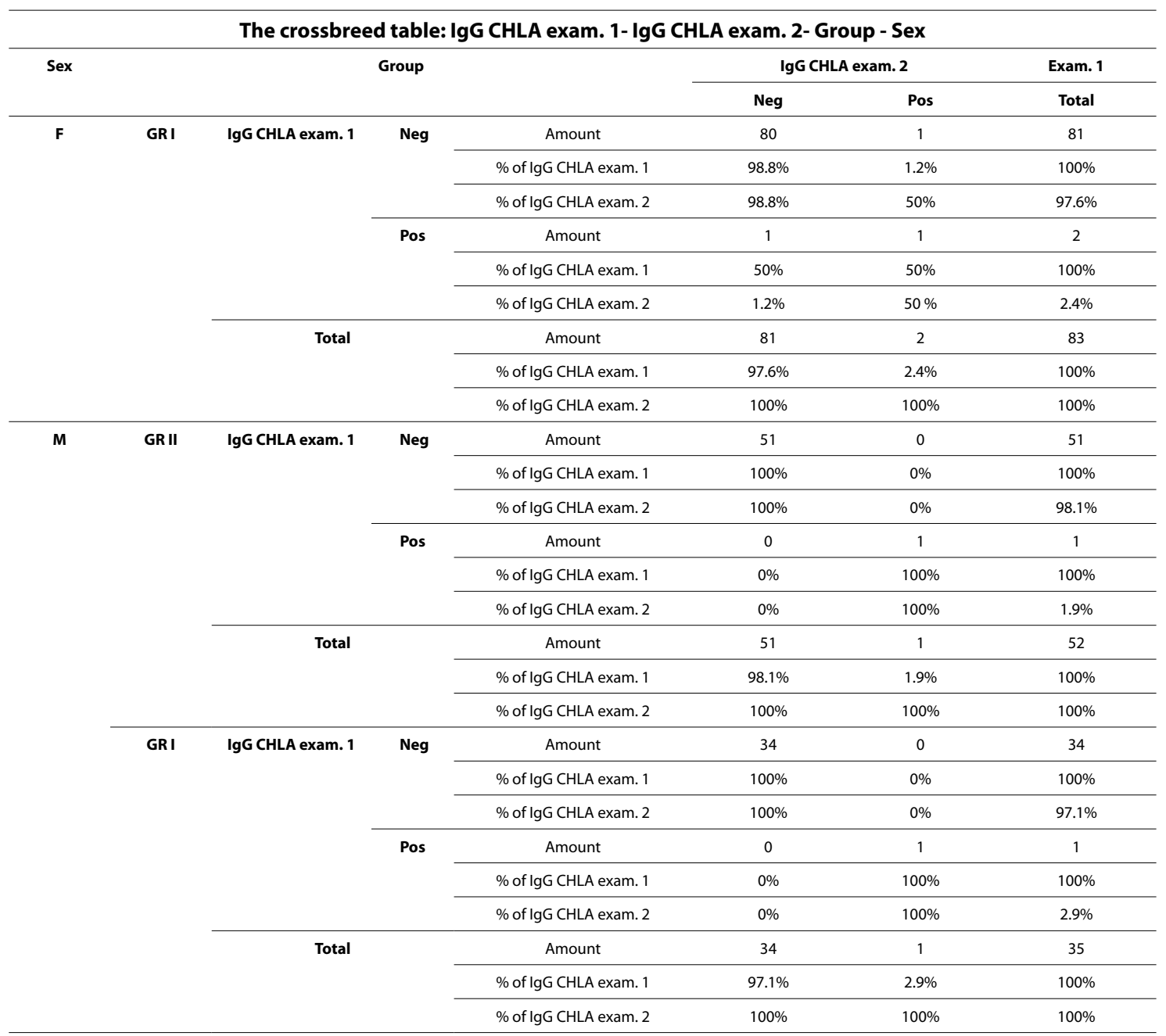

F-female, M-male

mune parameters in all patients were in the reference range.

Analysis of cytokine concentrations was impossible to assess due to a small number of patients infected with Chlamydia trachomatis.

\section{HPV infection}

The study involved a total of 567 subjects (162 women and 405 men). Study 2 involved 171 subjects ( 84 women, 87 men). HPV was detected by determining the DNA in the cells of the squamous epithelium of samples taken from the cervical canal or the sulcus behind the corona of the glans.

In Study 1, a total of 306 out of 567 persons left for missions abroad (Group II) and 261 persons remained in the country (Group I). In Study 1, HPV infection was not detected in 156 (51\%) patients in Group II and 201 (77\%) in Group I. Low-risk HPV infection was found in a total of 26 individuals, including 15 (4.9\%) cases in group II and 11 (4.2\%) cases in group I. High-risk infection was found in $36(6.3 \%)$ patients, including 15 (4.9\%) patients in Group II and 21 (8\%) patients in Group I. Mixed infections (high- and low- risk) were detected in 3 (5\%) cases - 2 (7\%) in Group II and 1 (4\%) in Group I. Due to small amount of sample material, HPV DNA could not be determined in 145 (25.6\%) cases out of 118 (38.6\%) in Group II and in 27 (10.3\%) in Group I.

A total of 171 individuals participated in Study 2, including 52 persons from Group II and 119 persons from Group I. No infection was detected in $121(70.8 \%)$ out of a group of 171 persons, including 31 patients (59.6\%) in Group II and 90 (75.6\%) patients in Group I. Low risk HPV infection was found in 5 individuals in Group I, whereas high risk HPV infection in 9 individuals (17.3\%) in Group II and in 7 individuals (5.9\%) in group I. Mixed infection was found in 1 person from Group I. Due to insufficient amount of sample material, HPV DNA 

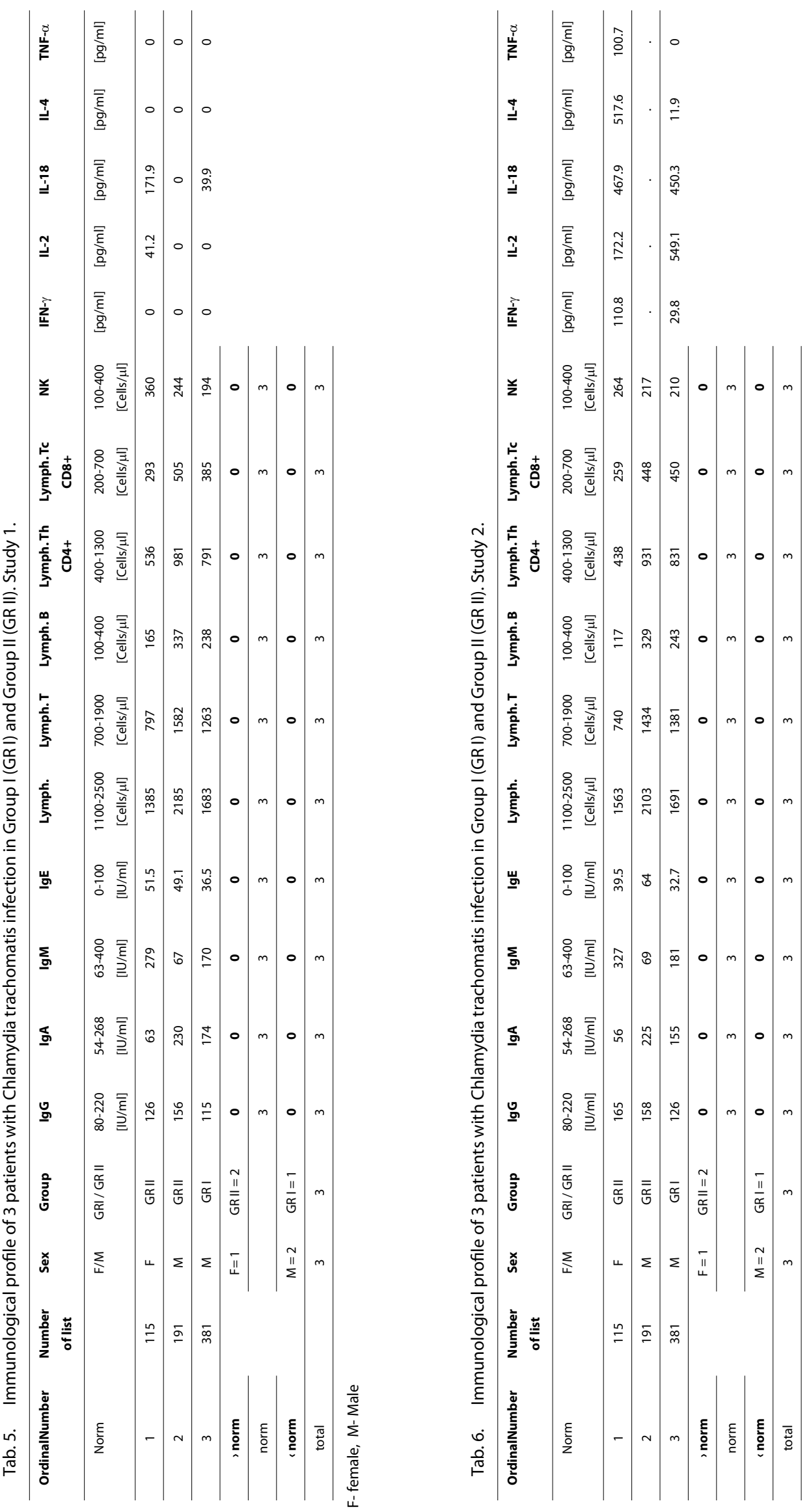

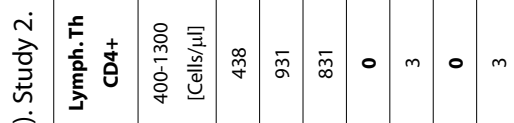

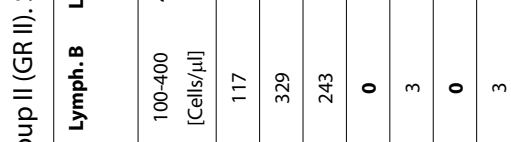

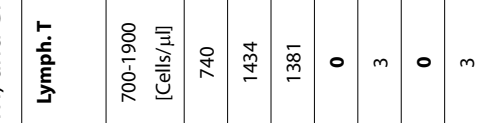

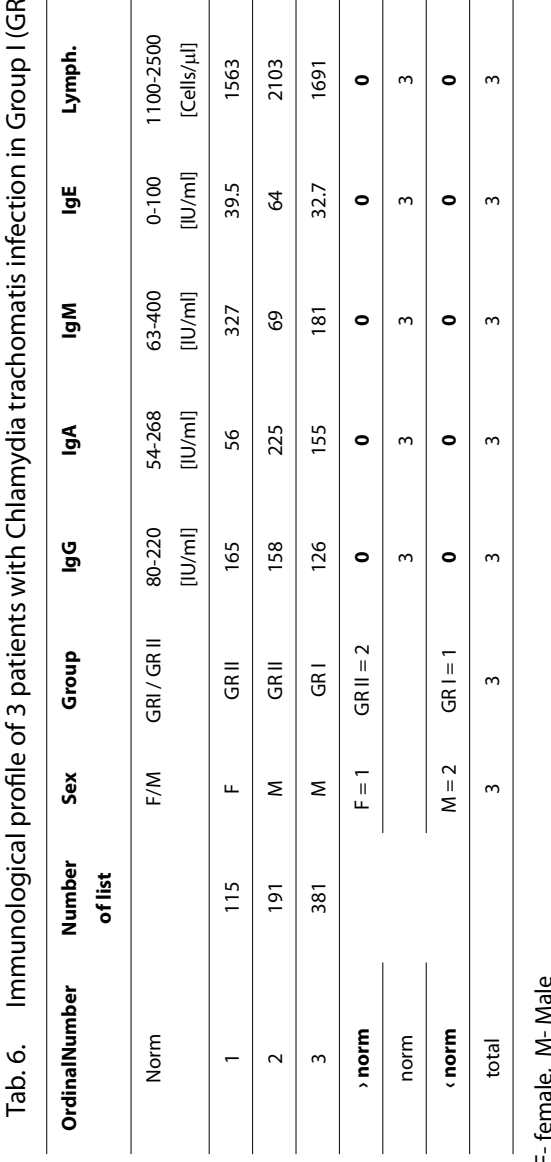


Original Article

Tab. 7. Changes in the dynamics of HPV infection in Group I and Group II (GR I, GR II) taking into account the type of virus and gender. Study 1 (exam.1) and Study 2 (exam. 2).

\begin{tabular}{|c|c|c|c|c|c|c|c|c|c|c|}
\hline \multicolumn{11}{|c|}{ The crossbreed table: HPV exam. 1 - HPV exam.2 - Group - Sex } \\
\hline \multirow[t]{2}{*}{ Sex } & \multicolumn{4}{|c|}{ Group } & \multicolumn{5}{|c|}{ HPV exam. 2} & \multirow{2}{*}{$\begin{array}{c}\text { Exam. } 1 \\
\text { total }\end{array}$} \\
\hline & & & & & $\begin{array}{l}\text { not detec- } \\
\text { ted }\end{array}$ & low risk & high risk & mixed & $\begin{array}{l}\text { too ILittle } \\
\text { DNA, not } \\
\text { detectable }\end{array}$ & \\
\hline \multirow[t]{15}{*}{$\mathrm{F}$} & \multirow[t]{15}{*}{ GRI } & \multirow[t]{15}{*}{ HPV exam. 1} & \multirow[t]{3}{*}{ Not detected } & Amount & 67 & 3 & 1 & 0 & 3 & 74 \\
\hline & & & & $\%$ of HPV exam. 1 & $90.5 \%$ & $4.1 \%$ & $1.4 \%$ & $0 \%$ & $4.1 \%$ & $100 \%$ \\
\hline & & & & $\%$ of HPV exam. 2 & $93.1 \%$ & $100 \%$ & $20 \%$ & $0 \%$ & $100 \%$ & $88.1 \%$ \\
\hline & & & \multirow[t]{3}{*}{ Low risk } & Amount & 0 & 0 & 1 & 0 & 0 & 1 \\
\hline & & & & $\%$ of HPV exam. 1 & $0 \%$ & $0 \%$ & $100 \%$ & $0 \%$ & $0 \%$ & $100 \%$ \\
\hline & & & & $\%$ of HPV exam. 2 & $0 \%$ & $0 \%$ & $20 \%$ & $0 \%$ & $0 \%$ & $1.2 \%$ \\
\hline & & & \multirow[t]{3}{*}{ High risk } & Amount & 4 & 0 & 3 & 1 & 0 & 8 \\
\hline & & & & $\%$ of HPV exam. 1 & $50.0 \%$ & $0 \%$ & $37.5 \%$ & $12.5 \%$ & $0 \%$ & $100 \%$ \\
\hline & & & & $\%$ of HPV exam. 2 & $5.6 \%$ & $0 \%$ & $60 \%$ & $100 \%$ & $0 \%$ & $9.5 \%$ \\
\hline & & & \multirow{3}{*}{$\begin{array}{l}\text { Too Little DNA, } \\
\text { not detectable }\end{array}$} & Amount & 1 & 0 & 0 & 0 & 0 & 1 \\
\hline & & & & $\%$ of HPV exam. 1 & $100 \%$ & $0 \%$ & $0 \%$ & $0 \%$ & $0 \%$ & $100 \%$ \\
\hline & & & & $\%$ of HPV exam. 2 & $1.4 \%$ & $0 \%$ & $0 \%$ & $0 \%$ & $0 \%$ & $1.2 \%$ \\
\hline & & & \multirow[t]{3}{*}{ otal } & Amount & 72 & 3 & 5 & 1 & 3 & 84 \\
\hline & & & & $\%$ of HPV exam. 1 & $85.7 \%$ & $3.6 \%$ & $6.0 \%$ & $1.2 \%$ & $3.6 \%$ & $100 \%$ \\
\hline & & & & $\%$ of HPV exam. 2 & $100 \%$ & $100 \%$ & $100 \%$ & $100 \%$ & $100 \%$ & $100 \%$ \\
\hline \multirow[t]{27}{*}{ M } & \multirow[t]{12}{*}{ GR II } & \multirow[t]{12}{*}{ HPV exam.1 } & \multirow[t]{3}{*}{ Not detected } & Amount & 20 & & 5 & & 8 & 33 \\
\hline & & & & $\%$ of HPV exam. 1 & $60.6 \%$ & & $15.2 \%$ & & $24.2 \%$ & $100 \%$ \\
\hline & & & & $\%$ of HPV exam. 2 & $64.5 \%$ & & $55.6 \%$ & & $66.7 \%$ & $63.5 \%$ \\
\hline & & & \multirow[t]{3}{*}{ Low risk } & Amount & 1 & & 2 & & 3 & 6 \\
\hline & & & & $\%$ of HPV exam. 1 & $16.7 \%$ & & $33.3 \%$ & & $50 \%$ & $100 \%$ \\
\hline & & & & $\%$ of HPV exam. 2 & $3.2 \%$ & & $22.2 \%$ & & $25 \%$ & $11.5 \%$ \\
\hline & & & \multirow{3}{*}{$\begin{array}{l}\text { Too Little DNA, } \\
\text { not detectable }\end{array}$} & Amount & 10 & & 2 & & 1 & 13 \\
\hline & & & & $\begin{array}{c}\% \text { of } \mathrm{HPV} \_\mathrm{b} 1=\mathrm{e}- \\
\text { xam.1 }\end{array}$ & $76.9 \%$ & & $15.4 \%$ & & $7.7 \%$ & $100 \%$ \\
\hline & & & & $\begin{array}{c}\% \text { of } \mathrm{HPV}_{-} \mathrm{b} 2=\mathrm{e}- \\
\text { xam. } 2\end{array}$ & $32.3 \%$ & & $22.2 \%$ & & $8.3 \%$ & $25.0 \%$ \\
\hline & & & \multirow[t]{3}{*}{ otal } & Amount & 31 & & 9 & & 12 & 52 \\
\hline & & & & $\%$ of HPV exam. 1 & $59.6 \%$ & & $17.3 \%$ & & $23.1 \%$ & $100 \%$ \\
\hline & & & & $\%$ of HPV exam. 2 & $100 \%$ & & $100 \%$ & & $100 \%$ & $100 \%$ \\
\hline & \multirow[t]{15}{*}{ GRI } & HPV_b1 & Not detected & Amount & 15 & 2 & 1 & & 6 & 24 \\
\hline & & & & $\%$ of HPV exam. 1 & $62.5 \%$ & $8.3 \%$ & $4.2 \%$ & & $25.0 \%$ & $100 \%$ \\
\hline & & & & $\%$ of HPV exam. 2 & $83.3 \%$ & $100 \%$ & $50 \%$ & & $46.2 \%$ & $68.6 \%$ \\
\hline & & & Low risk & Amount & 1 & 0 & 0 & & 1 & 2 \\
\hline & & & & $\%$ of HPV exam. 1 & $50 \%$ & $0 \%$ & $0 \%$ & & $50 \%$ & $100 \%$ \\
\hline & & & & $\%$ of HPV exam. 2 & $5.6 \%$ & $0 \%$ & $0 \%$ & & $7.7 \%$ & $5.7 \%$ \\
\hline & & & High risk & Amount & 0 & 0 & 1 & & 0 & 1 \\
\hline & & & & $\%$ of HPV exam. 1 & $0 \%$ & $0 \%$ & $100 \%$ & & $0 \%$ & $100 \%$ \\
\hline & & & & $\%$ of HPV exam. 2 & $0 \%$ & $0 \%$ & $50 \%$ & & $0 \%$ & $2.9 \%$ \\
\hline & & & Too Little DNA, & Amount & 2 & 0 & 0 & & 6 & 8 \\
\hline & & & not detectable & $\%$ of HPV exam. 1 & $25.0 \%$ & $0 \%$ & $0 \%$ & & $75.0 \%$ & $100 \%$ \\
\hline & & & & & $11.1 \%$ & $0 \%$ & $0 \%$ & & $46.2 \%$ & $22.9 \%$ \\
\hline & & & tal & Amount & 18 & 2 & 2 & & 13 & 35 \\
\hline & & & & $\%$ of HPV exam. 1 & $51.4 \%$ & $5.7 \%$ & $5.7 \%$ & & $37.1 \%$ & $100 \%$ \\
\hline & & & & $\%$ of HPV exam. 2 & $100 \%$ & $100 \%$ & $100 \%$ & & $100 \%$ & $100 \%$ \\
\hline
\end{tabular}

F-female, M-male 
was not determined in 28 (16.4\%) cases, including 12 (23.1\%) from Group II and 16 (13.4\%) from Group I.

In study 1, HPV infection was not detected in 74 out of 84 women (Table 7) from Group I. While in Study 2, the same group of women presented with the following results:

- no infection in 67 women, 3 women at low risk of infection, 1 woman with high risk of infection, undetermined data in 3 patients due to small amount of HPV DNA sample material,

- low-risk infection was confirmed in 1 case where high-risk HPV infection was identified in Study 2

- in Study 1, high-risk HPV infection was confirmed in 8 women in whom in Study 2: no infection was detected in 4 women, high-risk HPV infection was found in 3 women, and in 1 woman mixed-type infection was found,

- due to small amount of sample material, no HPV DNA determination was made in one person in Study 1 and Study 2.

In Group II, 33 out of 52 soldiers (Table 7) were negative for HPV infection in Study 1. In Study 2 conducted on the same group, the following results were found:

- no infection in 20 men. High-risk HPV infection was confirmed in 5 patients. In 8 cases HPV DNA was undetermined due to low amount of sample material,

- in 6 cases low-risk HPV infection was confirmed in Study 1 . In study 2 of the same group HPV DNA could not be determined, in 3 cases, while in 2 soldiers infection with high-risk was confirmed, and no infection was not detected in 1 person,

- in study 1, undetermined HPV DNA was found in 13 men. In study 2 of the same group, highrisk infection was found in 2 patients, no infection was detected in 10 patients, in 1 case HPV DNA was undetermined.

In the first group consisting of 35 men (Table

7), HPV infection was not detected in 24 patients in Study 1. In Study 2, the same group presented with the following:

- re-infection was not detected in 15 cases. Lowrisk infection was found in 2 individuals. High-risk infection was confirmed in 1 person. In 6 cases HPV DNA was undetermined due to small amount of sample material,

- in study 1, low-risk infection was confirmed in 2 men. In study 2 , one of them was not confirmed, while in the second case HPV DNA was not determined due to small amount of sample material,

- high-risk HPV infection was found in 1 man in Study 1 and later confirmed in Study 2,
- in Study 1, HPV DNA was undetermined in 8 patients. In Study 2, HPV infection was not detected in 2 cases, while in 6 instances HPV DNA was undetermined due to small amount of sample material.

Immunological parameter results of patients in which HPV infection was found in Studies 1 and 2 (8 out of 65 positives in Study 1 and 8 out of 22 positives in Study 2; 5 women and 3 men) are shown in Tables 8 and 9. Six persons belong to Group I, while 2 individuals belong to Group II.

There was no impairment in humoral immunity in Study 1 (Table 8) and Study 2 (Table 9). In Study 1 , reduced levels of CD4 were fond in one person and reduced levels of NK cells also in 1 person. In Study 2, reduced number of NK cells was confirmed in one person.

An analysis of cytokine concentrations showed a decline in the median plasma levels of IL-18 in Study 2 as compared to Study 1 . Concentration analysis of other cytokines was impossible to perform.

The analysis showed a decrease in the median concentration of IL-18 in Study 2, as compared to the median concentration of IL-1. Concentration analysis of other cytokines was impossible to perform.

\section{Determination of E6 and E7 gene mRNA of highly-oncogenic HPV types $(16,18,31$, 33, 45)}

The analysis was performed once in a group of 200 women ages 20-35 years. E6/E7 mRNA transcripts were detected in 17 women (Table 10). HPV 16 infection was detected in 15 women (including 1 case of mixed infection with HPV18 and 1 with HPV33). In one case, only HPV18 infection was diagnosed, while in another only HPV33 was detected.

Pap smears were performed in all cases. HPV16 infection was diagnosed in 2 patients with group I cytology (based on Papanicolaou). These women did not have a history of inflammation. In 2 cases, two types of HPV infection were diagnosed (16 and 18 , and 16 and 33). Both patients had changes in the endothelial cells, one had high-level HSIL, the other LSIL/CIN1. A history of recurrent inflammation of the genital tract was reported in both women. In a third patient with confirmed HPV16 infection cytology showed intraepithelial lesions, including high-level koilocytosis and the probability of CIN1. History taking revealed recurrent inflammation of the genital tract was determined. Recurrent inflammation of the genital tract and Group II cytology were found during the examination in 14 patients. 


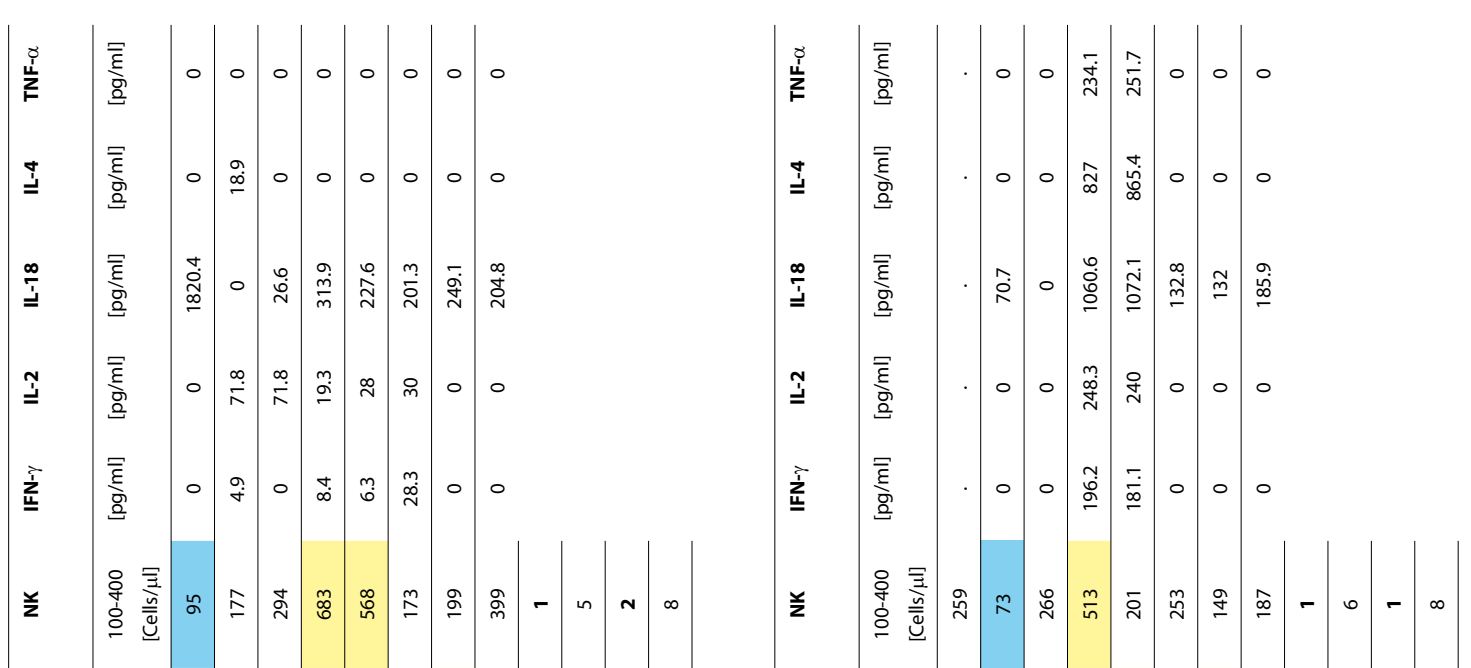

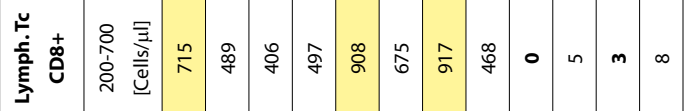

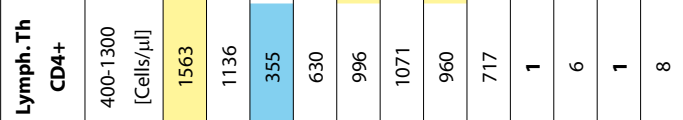

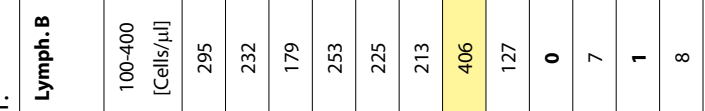

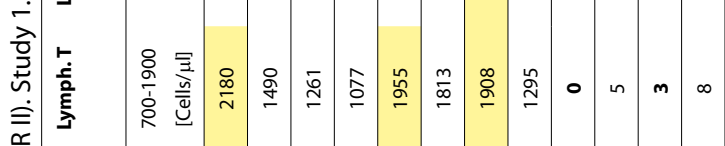

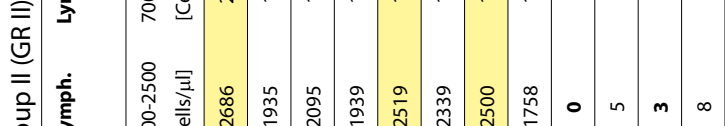

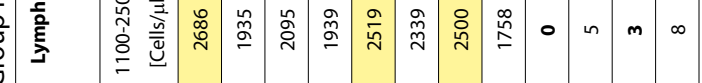

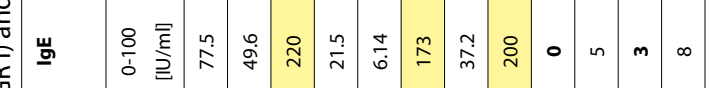

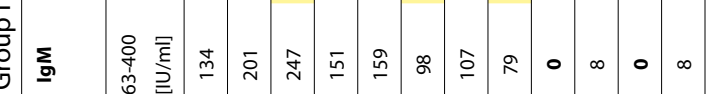

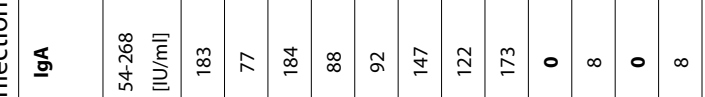

高

g

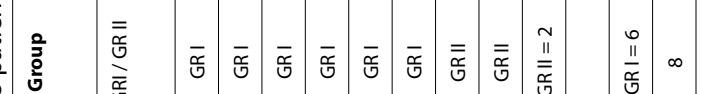

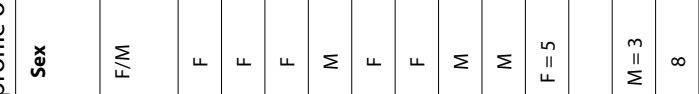

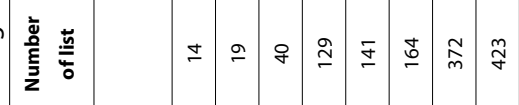

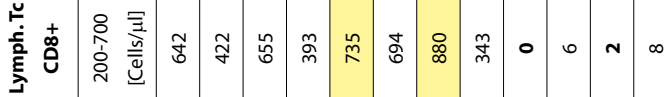

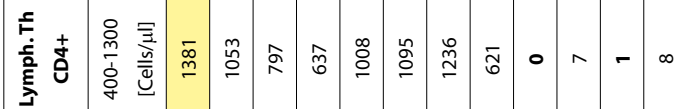

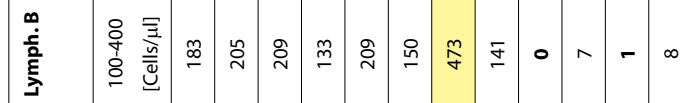



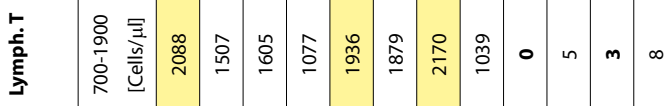

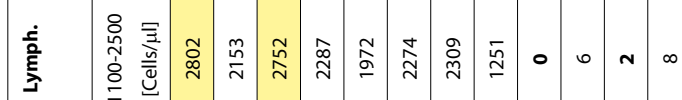

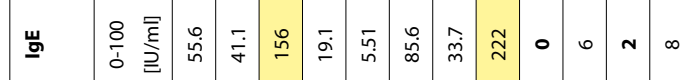

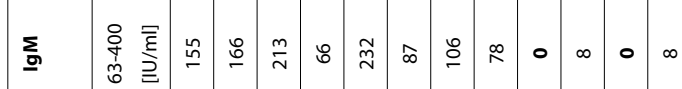

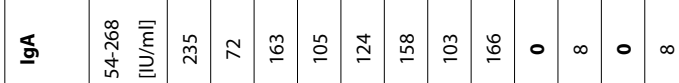

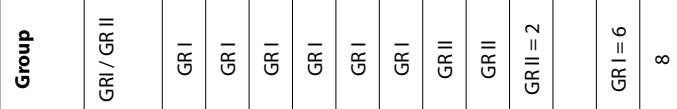

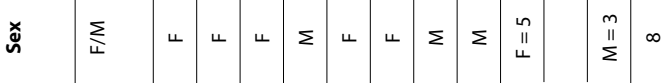

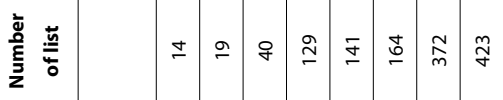

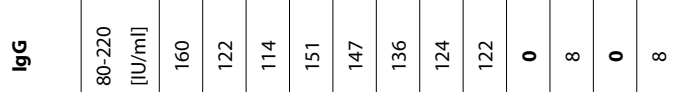


M. Gołębiowska-Wawrzyniak and al. - Sexually transmitted infections...

Tab. 10. Prevalence of high-risk HPV types among 17 infected women.

\begin{tabular}{|c|c|c|c|c|c|c|}
\hline Ordinal Number & Patient & HPV16 & HPV18 & HPV31 & HPV33 & HPV45 \\
\hline 1 & S.A. & 1 & 0 & 0 & 1 & 0 \\
\hline 2 & S.S & 1 & 1 & 0 & 0 & 0 \\
\hline 3 & B.M. & 1 & 0 & 0 & 0 & 0 \\
\hline 4 & N.O. & 1 & 0 & 0 & 0 & 0 \\
\hline 5 & K.L. & 1 & 0 & 0 & 0 & 0 \\
\hline 6 & K.I. & 1 & 0 & 0 & 0 & 0 \\
\hline 7 & M.A. & 1 & 0 & 0 & 0 & 0 \\
\hline 8 & K.J. & 1 & 0 & 0 & 0 & 0 \\
\hline 9 & G.M. & 1 & 0 & 0 & 0 & 0 \\
\hline 10 & T.M. & 1 & 0 & 0 & 0 & 0 \\
\hline 11 & B.E. & 1 & 0 & 0 & 0 & 0 \\
\hline 12 & K.W. & 1 & 0 & 0 & 0 & 0 \\
\hline 13 & S.E. & 1 & 0 & 0 & 0 & 0 \\
\hline 14 & Ż.E. & 1 & 0 & 0 & 0 & 0 \\
\hline 15 & Ł.U. & 1 & 0 & 0 & 0 & 0 \\
\hline 16 & M.E. & 0 & 0 & 0 & 1 & 0 \\
\hline 17 & D.P. & 0 & 1 & 0 & 0 & 0 \\
\hline
\end{tabular}

Based on the results of our own research and the literature, it appears that the determination of E6/E7 transcripts will become an important testing method for cervical cancer. However, this test detects fewer women with positive results than the HPV DNA tests, but it can find exactly those cases, which definitely need further diagnostic workup and observation.

\section{HIV infection}

A total of 750 HIV tests were performed, all the results were negative.

\section{Healthy patients}

The group of patients with no confirmed HSV2, Chlamydia trachomatis, HIV or HPV infections consisted of 124 women and 214 men. A total of 186 patients in Group I and 152 patients in Group II. In study 1 , impaired humoral immunity as a reduction in IgG concentration was confirmed in 6 out of 338 patients, IgA in 13 cases and IgM in 49 cases. Elevated lgE levels were observed in 79 patients in Study I. Impaired cellular immunity, as a reduction in the number of T cells, was confirmed in 10 patients, B-cell lymphoma in 26 patients, CD4 in 7 patients, CD8 in 8 patients and NK cells in 47 cases.

Study 2 was conducted on 106 patients, including 60 women and 46 men. Group I consisted of 77 patients, while Group II was made up of 29 patients. In a group of 106 subjects in Study 2 , humoral immunity impairment as determined by reduced IgG concentration was confirmed in 1 person, IgA in 6 patients, IgM in 11 patients. Elevated IgE concentration occurred in 17 Study 2 patients. Impaired cellular immunity as determined by reduction in the number of $T$ cells was observed in 3 patients, B-cell lymphoma in 6 patients, CD4 in 3 patients, CD8 in 1 patient and NK cells in 13 patients.

In a group of 87 patients selected from among 338 individuals (tested twice) in Study 1 (Table 11), impaired humoral immunity in the form of a reduction in IgG concentration was confirmed in 6 patients, IgA in 13 cases and IgM in 49 patients. In Study 1, elevated levels of IgE were found in 79 patients. Impaired cellular immunity as a reduction in the number of $T$ cells was confirmed in 10 patients, B-cell lymphoma in 26 patients, CD4 in 7 patients, CD8 in 8 patients and NK cells in 47 patients.

Tab. 11. Immunological profile of 87 selected patients (repeatedly examined) with no HSV, Chlamydia trachomatis, HIV or HPV infection.

\begin{tabular}{|c|c|c|c|c|c|c|c|c|c|c|c|c|c|c|c|c|}
\hline$\%$ & Sex & $\begin{array}{c}\text { Gro- } \\
\text { up }\end{array}$ & $\begin{array}{c}\text { Amo- } \\
\text { unt }\end{array}$ & $\%$ & IgG & $\lg A$ & $\lg M$ & $\lg E$ & $\%$ & WBC & Lymph. & $\begin{array}{c}\text { Lymph. } \\
\text { T }\end{array}$ & $\begin{array}{c}\text { Lymph. } \\
\text { B }\end{array}$ & $\begin{array}{c}\text { Lymph. } \\
\text { Th } \\
\text { CD4+ }\end{array}$ & $\begin{array}{l}\text { Lymph. } \\
\text { Tc CD8+ }\end{array}$ & NK \\
\hline $\mathrm{F}$ & 55 & II & 18 & < norm & 1 & 6 & 11 & 0 & inorm & 3 & 4 & 3 & 6 & 3 & 1 & 13 \\
\hline$M$ & 32 & 1 & 69 & norm & 84 & 81 & 76 & 70 & norm & 83 & 68 & 71 & 73 & 76 & 70 & 62 \\
\hline \multirow[t]{2}{*}{ Total } & 87 & Total & 87 & , norm & 2 & 0 & 0 & 17 & , norm & 0 & 14 & 12 & 7 & 7 & 15 & 11 \\
\hline & & & & Total & 87 & 87 & 87 & 87 & Total & 86 & 86 & 86 & 86 & 86 & 86 & 86 \\
\hline $\mathrm{F}$ & 63.2 & II & 20.7 & ( norm & 1.1 & 6.9 & 12.6 & 0 & inorm & 3.5 & 4.7 & 3.5 & 7 & 3.5 & 1.2 & 15.1 \\
\hline$M$ & 36.8 & 1 & 79.3 & norm & 96.6 & 93.1 & 87.4 & 80.5 & norm & 96.5 & 79.1 & 82.6 & 84.9 & 88.4 & 81.4 & 72.1 \\
\hline \multirow[t]{2}{*}{ Total } & 100 & Total & 100 & > norm & 2.3 & 0 & 0 & 19.5 & inorm & 0 & 16.3 & 14 & 8.1 & 8.1 & 17.4 & 12.8 \\
\hline & & & & Total & 100 & 100 & 100 & 100 & Total & 100 & 100 & 100 & 100 & 100 & 100 & 100 \\
\hline $\begin{array}{l}\text { Valid } \\
\text { cases }\end{array}$ & 87 & & 87 & & 87 & 87 & 87 & 87 & & 86 & 86 & 86 & 86 & 86 & 86 & 86 \\
\hline $\begin{array}{l}\text { No } \\
\text { data }\end{array}$ & 0 & & 0 & & 0 & 0 & 0 & 0 & & 1 & 1 & 1 & 1 & 1 & 1 & 1 \\
\hline
\end{tabular}

F- female, M- Male. Study 1 
Original Article

Tab. 12. Immunological profile of 87 selected patients (re-examined) with no HSV, Chlamydia trachomatis, HIV or HPV infection.

\begin{tabular}{|c|c|c|c|c|c|c|c|c|c|c|c|c|c|c|c|c|}
\hline$\%$ & Sex & $\begin{array}{l}\text { Gro- } \\
\text { up }\end{array}$ & $\begin{array}{c}\text { Amo- } \\
\text { unt }\end{array}$ & $\%$ & IgG & $\operatorname{Ig} A$ & IgM & IgE & $\%$ & WBC & Lymph. & $\begin{array}{c}\text { Lymph. } \\
\text { T }\end{array}$ & $\begin{array}{c}\text { Lymph. } \\
\text { B }\end{array}$ & $\begin{array}{c}\text { Lymph. } \\
\text { Th } \\
\text { CD4+ }\end{array}$ & $\begin{array}{l}\text { Lymph. } \\
\text { Tc CD8+ }\end{array}$ & NK \\
\hline $\mathrm{F}$ & 55 & II & 18 & \& norm & 0 & 4 & 5 & 0 & \& norm & 1 & 4 & 2 & 5 & 2 & 3 & 14 \\
\hline M & 32 & 1 & 69 & norm & 83 & 82 & 81 & 70 & norm & 86 & 67 & 72 & 77 & 78 & 75 & 65 \\
\hline \multirow[t]{2}{*}{ Total } & 87 & Total & 87 & > norm & 3 & 0 & 0 & 16 & , norm & 0 & 16 & 13 & 5 & 7 & 9 & 8 \\
\hline & & & & Total & 86 & 86 & 86 & 86 & Total & 87 & 87 & 87 & 87 & 87 & 87 & 87 \\
\hline K & 63.2 & II & 20.7 & inorm & 0 & 4.7 & 5.8 & 0 & inorm & 1.1 & 4.6 & 2.3 & 5.7 & 2.3 & 3.4 & 16.1 \\
\hline$M$ & 36.8 & I & 79.3 & norm & 96.5 & 95.3 & 94.2 & 81.4 & norm & 98.9 & 77 & 82.8 & 88.5 & 89.7 & 86.2 & 74.7 \\
\hline \multirow[t]{2}{*}{ Total } & 100.0 & Total & 100.0 & , norm & 3.5 & 0 & 0 & 18.6 & , norm & 0 & 18.4 & 14.9 & 5.7 & 8 & 10.3 & 9.2 \\
\hline & & & & Total & 100 & 100 & 100 & 100 & Total & 100 & 100 & 100 & 100 & 100 & 100 & 100 \\
\hline $\begin{array}{l}\text { Valid } \\
\text { cases }\end{array}$ & 87 & & 87 & & 86 & 86 & 86 & 86 & & 87 & 87 & 87 & 87 & 87 & 87 & 87 \\
\hline $\begin{array}{l}\text { No } \\
\text { data }\end{array}$ & 0 & & 0 & & 1 & 1 & 1 & 1 & & 0 & 0 & 0 & 0 & 0 & 0 & 0 \\
\hline
\end{tabular}

F- female, M- Male. Study 2

Tab. 13. Cytokine profile of 87 selected patients (re-examined) negative for HSV, Chlamydia trachomatis, HIV and HPV infection.

\begin{tabular}{|c|c|c|c|c|c|c|c|c|c|c|}
\hline \multirow{2}{*}{$\begin{array}{l}\text { Descriptive } \\
\text { stats }\end{array}$} & \multicolumn{5}{|c|}{ Exam. $1 \mathrm{n}=84$} & \multicolumn{5}{|c|}{ Exam. $2 n=84$} \\
\hline & $\mathrm{IFN}-\gamma$ & IL-2_ & IL-18 & IL-4 & TNF- $\alpha$ & $\mathrm{IFN}-\gamma$ & IL-2 & IL-18 & IL-4 & TNF- $\alpha$ \\
\hline $\begin{array}{l}\text { Value above } \\
\text { zero }\end{array}$ & 40 & 55 & 73 & 43 & 24 & 32 & 37 & 81 & 35 & 25 \\
\hline zero value & 44 & 29 & 11 & 41 & 60 & 52 & 47 & 3 & 49 & 59 \\
\hline$\%$ of zero value & $52.4 \%$ & $34.5 \%$ & $13.1 \%$ & $48.8 \%$ & $71.4 \%$ & $61.9 \%$ & $56 \%$ & $3.6 \%$ & $58.3 \%$ & $70.2 \%$ \\
\hline mean & 648.4 & 267.5 & 903.6 & 1064.5 & 255.1 & 480 & 288.3 & 736.6 & 902.1 & 419.1 \\
\hline $\begin{array}{l}\text { Standard error } \\
\text { of the mean }\end{array}$ & 239.6 & 57.8 & 156.8 & 242.4 & 88.6 & 157 & 95.7 & 195.1 & 190.2 & 224.3 \\
\hline Median & 51.7 & 117.6 & 370.5 & 648.8 & 46.2 & 182.5 & 201.4 & 295.7 & 797.7 & 221.8 \\
\hline Dominant & 9.3 & 33.4 & 27.4 & 1084.3 & 7.3 & 22.4 & 242.7 & 279.9 & 11.8 & 267.3 \\
\hline $\begin{array}{l}\text { Standard } \\
\text { deviation }\end{array}$ & 1515.6 & 429.0 & 1339.9 & 1589.2 & 433.9 & 888.4 & 582.2 & 1755.6 & 1125.2 & 1121.4 \\
\hline range & 6681 & 2438.1 & 6945.1 & 7198.3 & 1611.1 & 3843.1 & 3304.8 & 14349.5 & 5141.1 & 5761 \\
\hline Min & 1.4 & 9.4 & 24.9 & 1.7 & 7.3 & 2.5 & 4.3 & 54.4 & 11.8 & 1.2 \\
\hline Max & 6682.4 & 2447.5 & 6970.0 & 7200.0 & 1618.4 & 3845.6 & 3309.1 & 14403.8 & 5152.9 & 5762.3 \\
\hline Percentiles & & & & & & & & & & \\
\hline 5 & 2.8 & 17.4 & 27.4 & 14.9 & 8 & 6.9 & 11.9 & 74.2 & 11.9 & 1.9 \\
\hline 10 & 9.3 & 21.7 & 32.7 & 22.9 & 10.7 & 22.4 & 16.4 & 103.4 & 32.7 & 5 \\
\hline 25 & 11.2 & 33.2 & 208.6 & 92.3 & 24.1 & 65.1 & 37.8 & 171.4 & 113.7 & 142.4 \\
\hline 50 & 51.7 & 117.6 & 370.5 & 648.8 & 46.2 & 182.5 & 201.4 & 295.7 & 797.7 & 221.8 \\
\hline 75 & 178.2 & 328.6 & 671.1 & 1204.4 & 325.1 & 247 & 249.6 & 921.1 & 926.8 & 253 \\
\hline 90 & 3658.7 & 679.3 & 3214.5 & 2790.2 & 1133.1 & 2149.5 & 506.1 & 1089.1 & 2772.5 & 440.5 \\
\hline 95 & 4941.1 & 1334.4 & 4027.1 & 6248.1 & 1513.1 & 3066.2 & 1581.6 & 1397.9 & 4179.6 & 4234 \\
\hline
\end{tabular}

F- female, M- Male. Study 1 and 2

In Study 2 (Table 12), impaired humoral immunity in the form of reduced levels of $\lg A$ antibodies occurred in 4 patients, IgM in 11 patients. In Study 2, elevated serum IgE levels were detected in 16 patients. Impaired cellular immunity as a reduction in the number of T cells occurred in 2 patients,
B-cell lymphoma in 5 patients, CD4 in 2 patients, CD8 in 3 patients and NK cells in 14 patients.

In a group of patients earlier determined to have no HSV2, Chlamydia trachomatis, HIV and HPV infection, the cytokine values contain a high proportion of zero values. Positive values for each cytokine create various range values depending 
on tests 1 and 2: IFN-g (52-64\%), IL-2 (34-56\%), IL-4 (48-64\%), TNF-a (69-74\%) and IL-18 (3-13\%) in Study 1 and 2 (Table 13). Cytokine distributions that are different from the norm are concentrated on small values; therefore the mean value and standard deviation do not properly depict their characteristics. The median values for each cytokine in Study 1 and Study 2 are different enough that they do not form any specific pattern, as shown by the percentile distribution and histograms.

\section{SUMMARY}

Research concerning sexually transmitted infections in the residual forces participating in military missions was made under the Development Project Number O R00002405. This is the first innovative research of such type carried out among groups of uniformed services personnel that pertains the frequency of sexually transmitted infections taking into account immunodeficiency. Accordingly, the discussion was replaced by an extended summary.

Frequency of the analyzed HPV, HIV, HSV2, Chlamydia trachomatis infections and the selected immunological parameters of the groups tested have trended favorably in comparison with the rate of infection in the general Polish population. The study shows that the incidence of sexually transmitted infections is lower than that described in the world literature [11] Barkin D.M. "The global health burden of infection-associated cancers in the year 2002". Int. Journ. Cancer. 2006.

There are no significant differences in the comparative analysis of Group I (patients remaining in the country) and Group II (temporarily residing abroad). The completed studies have not found an increase in the incidence of HSV-2, Chlamydia trachomatis, HIV or HPV infections in a group of patients going on missions abroad, as compared to those remaining in the country. It should also be noted that Group II consisted of fewer subjects (extended stay out of the country resulted in a lower number of tests being performed in this group).
A slight immunodeficiency was occasionally detected and was unrelated to the confirmed infections. Increased IgE concentration was found in $22 \%$ of patients with no obvious symptoms of allergic disease. There was no association between sexually transmitted infections and elevated levels of IgE. Especially interesting are the results of a study concerning prevalence of HPV infection, particularly with the use of mRNA genes E6 and E7. Previously developed diagnostic algorithm for the detection of HPV infection has not yet fully utilized the significance of mRNA tests in the potential diagnosis of cervical cancer caused by this pathogen. It is recommended to perform the mRNA E6 and E7 gene tests in males. Incidence of sexually transmitted infections in women departing on missions abroad remains an open issue, largely due to the difficulty in reaching these patients.

\section{CONCLUSIONS}

1. In the groups studied, the frequency of analyzed HPV, HIV, HSV2 and Chlamydia trachomatis infection is lower than the rate published in the world literature and comparable to the rate of infection occurring in the general Polish population.

2. There are no significant differences between comparative analysis of Group I (persons remaining in the country) and Group II (persons temporarily residing abroad). Completed studies have not confirmed an increase in incidence of HSV2, Chlamydia trachomatis, HIV or HPV infections in a group of individuals going on military missions abroad compared to those remaining in the country.

\section{AUTHORS' DECLARATION:}

Study Design: Maria Gołębiowska-Wawrzyniak, Katarzyna Markiewicz; Data Collection: Maria Gołębiowska-Wawrzyniak; Statistical Analysis: Maria Gołębiowska-Wawrzyniak, Katarzyna Markiewicz, Tomasz Maciejewski, Artur Jakimiuk, Olaf Truszczyński, Tomasz Kozicki, Andrzej Modrzejewski, Agata Kozar, Zbigniew Wawrzyniak, Krzysztof Rytwiński; Manuscript Preparation: Maria Gołębiowska-Wawrzyniak; Funds Collection: Maria Gołębiowska-Wawrzyniak, Katarzyna Markiewicz, Agata Kozar, Zbigniew Wawrzyniak, Krzysztof Rytwiński. The Authors declare that there is no conflict of interest. 


\section{REFERENCES}

1. Anttila, T., et al. (2001) Serotypes of Chlamydia trachomatis and risk for development of cervical squamous cell carcinoma. JAMA. 285 (1). 47-51.

2. Chil, A. (2007) Metody wykrywania zakażeń wirusem HPV. Aktualności Biomerieux. 42. 19-23.

3. Cusini, M., Ghislanzoni, M. (2001) The importance of diagnosing genital herpes. Journ of Antimicrob. Chemiother. 47. 9-16.

4. Friedek, D., Ekiel, A., Martirosian, G. (2005). Chlamydia Trachomatis: etiopatogeneza i diagnostyka zakażeń. Przegląd Epidemiologiczny. 59. 723-730.

5. Jansen, K.U., Shaw, A. R. (2004) Human Papillomavirus Vaccines and Prevention of Cervical Cancer. Annual Review of Medicine. 55. 319-331.

6. Kędzia, W. (2009) Identyfikacja mRNA genów E6/E7 ludzkiego wirusa brodawczaka w wymazach z szyjki macicy kobiet z nieprawidłowym wynikiem cytologicznym. Aktualności Biomerieux. 50. 8-10.

7. Looker, K.J., Garnett, G.P., Schmid, G.P. (2008) An estimate of the global prevalence and incidence of herpes simplex virus type 2 infection. Bulletin of the World Health Organization [Online] Available from: http://www.who.int/bulletin/volumes/86/10/07-046128/en/ [Accessed: 16 December 2012]

8. Majewski, S. \& Sikorski, M. (2006) Szczepienia przeciw HPV. Profilaktyka raka szyjki macicy i innych zmian związanych z zakażeniami HPV. Lublin: CZELEJ.

9. Molden, T., Nygard, F., Kraus, I. (2005) Predicting CIN2+ when detecting HPV mRNA and DNA by PreTect HPV- proofer and consensus PCR: 2-year follow-up of women with ASCUS or LSIL Pap smear. Int. Journ. Cancer. 117. 973-976.

10. Osiński, M. (2010) Zakażenia chlamydialne jako interdyscyplinarny problem kliniczny. Chlamydiozy w różnych dyscyplinach medycznych. Medycyna Rodzinna. 3. 16-28.

11. Poland. Ministry of National Defence (2005) Służba wojskowa kobiet w SZ RP - 2005 r. [Online] Available from: www.mon. gov.pl [Accessed: 16 December 2012]

12. Poland. Ministry of National Defence (2008) Status kobiet $w$ armii [Online] Available from: www.mon.gov.pl [Accessed: 14 August 2009]

13. Poland. National Aids Centre (2012) Raporty z badań ewaluacyjnych [Online] Available from: www.aids.gov.pl [Accessed: 30 December 2012]

14. Rudnicka, l., Majewski, S. (2009) Choroby przenoszone drogą płciową w Polsce w 2007r. Przegląd Epidemiologiczny. 63. 289-291.

15. Serwin, A.B., Musiałkowska, E., Chodynicka, B. (2010) Opryszczka narządów płciowych - nadal istotny problem epidemiologiczny i kliniczny. Przegląd Epidemiologiczny. 64. 381-385.

16. Stokłosa, T. (2009) Niedobory odporności. In: Gołąb, J. (eds.) Immunologia. Warszawa: Wyd. PWN.

17. Tamim, H., Finan, R.R., Sharida, H.E. (2002) Cervicovaginal coinfections with human papillomavirus and Chlamydia trachomatis. Diagn. Microbil. Infect. Dis. 43 (4). 227-281.

18. Walczak, L., Majewski, S., Jabłońska, S. (2006) Zakażenia genitalnymi typami HPV u mężczyzn jako czynnik ryzyka rozwoju raka szyjki macicy u kobiet. In: Majewski, S. \& Sikorski, M. (eds.): Szczepienia przeciw HPV. Profilaktyka raka szyjki macicy i innych zmian związanych z zakażeniami HPV. Lublin: Wyd. CZELEJ.

19. Wald, A. (2004) Herpes simpleks virus type 2 transmission: risk factors and viralshedding. Herpes. 11 (Suppl 3). 130A-137A.

20. Wright, J. et al. (2006). Sexually transmitted diseases in Operation Iraqi Freedom / Operation Enduring Freedom. Military Medicine. 171 (10). 1024-1026.

21. Zbroch, T. et al. (2004) Wpływ zakażenia Chlamydia trachomatis i bacterial vaginosis oraz stylu życia na występowanie zmian szyjki macicy. Ginekologia Polska. 75 (7). 538-544.

Cite this article as: Gołębiowska-Wawrzyniak $\mathrm{M}$ and al.: Sexually transmitted infections in the residual forces participating in military missions - diagnostic and prophylactic proceedings. Pol J Aviat Med Psychol, 2013; 19(1): 21-36. 